\title{
Searching for Progress on Food Security in the North American North: A Research Synthesis and Meta-analysis of the Peer-Reviewed Literature
}

\author{
Philip A. Loring ${ }^{1}$ and S. Craig Gerlach ${ }^{2}$
}

(Received 18 August 2014; accepted in revised form 7 November 2014)

\begin{abstract}
Food security is a global societal challenge, and one geographic region where food insecurity is increasing is the North American Arctic and Subarctic. In this paper we synthesize research on food security in this region; important precursors and early work include reports on the impacts of land claims, the cumulative effects of industrial development and environmental change, and the health impacts of the nutrition transition among Indigenous peoples. Building on these foundations, food security research in the North has followed a path similar to that taken in the global food security literature, beginning with nutritional adequacy and security of food supplies and then downscaling to a focus on issues at the livelihood and household level. Our meta-analysis of the peer-reviewed literature reveals many reasons why people are food-insecure: challenges such as remoteness, climate change, and the high costs of food and fuel all play important roles. However, the primary drivers of food insecurity that we identify in this review relate to governance and policy challenges that have been recognized and critiqued for decades. Recommendations for future research include an improved focus on participatory research and food security interventions that acknowledge and focus on supporting the rights of local peoples to pursue food security on their own terms. This paper is relevant in the context of climatic and environmental change because it captures the role of shifting political ecologies as increased geopolitical interests in the North appear to be obscuring the rights and needs of local peoples to access and control their own land and resources.
\end{abstract}

Key words: Alaska Natives; Canada First Nations; climate change; development; food security; food sovereignty; governance; Indigenous peoples; social justice

RÉSUMÉ. De par le monde, l'insécurité alimentaire constitue un enjeu du point de vue de la société. L'Arctique et la région subarctique de l'Amérique du Nord sont des régions géographiques où l'insécurité alimentaire prend de l'ampleur. Dans cette communication, nous faisons la synthèse des travaux de recherche effectués au sujet de la sécurité alimentaire dans cette région. Parmi les précurseurs et les premiers travaux importants réalisés à ce sujet, notons des rapports sur les incidences des revendications territoriales, les effets cumulatifs du développement industriel et des changements sur l'environnement, de même que les effets sur la santé découlant de la transition alimentaire chez les peuples indigènes. S'appuyant sur ces assises, les recherches sur la sécurité alimentaire dans le Nord ont été conçues ni plus ni moins comme les autres études en matière de sécurité alimentaire dans le monde. Les recherches ont d'abord porté sur le caractère adéquat de l'alimentation et sur la sécurité des approvisionnements alimentaires, après quoi elles se sont concentrées sur des enjeux plus spécifiques comme ceux propres aux moyens de subsistance et aux ménages. Notre méta-analyse de la documentation révisée par des pairs a permis de révéler de nombreuses raisons pour lesquelles les gens sont aux prises avec l'insécurité alimentaire : des difficultés liées à l'éloignement, au changement climatique de même qu'au coût élevé de la nourriture et au carburant jouent toutes un rôle dans l'insécurité alimentaire. Cependant, les principaux facteurs de l'insécurité alimentaire cernés dans le cadre de notre analyse ont trait à la gouvernance et aux politiques, celles-ci faisant l'objet de critiques depuis des dizaines d'années. Les recommandations veulent que d'autres travaux de recherche soient davantage centrés sur la recherche participative et sur les interventions en matière de sécurité alimentaire, interventions qui permettent de reconnaître et de favoriser les droits des personnes locales pour qu'elles puissent atteindre la sécurité alimentaire selon leurs propres conditions. Cette communication est pertinente dans le contexte des changements climatiques et environnementaux parce qu'elle saisit le rôle des écologies politiques en pleine évolution au moment où les intérêts géopolitiques dans le Nord semblent obscurcir les droits et les besoins des gens de ces régions en ce qui a trait à l'accès et au contrôle de leurs propres terres et ressources.

Mots clés : Autochtones de l'Alaska; Premières Nations du Canada; changement climatique; développement; sécurité alimentaire; souveraineté alimentaire; gouvernance; peuples indigènes; justice sociale

Traduit pour la revue Arctic par Nicole Giguère.

\footnotetext{
${ }^{1}$ Corresponding author: School of Environment and Sustainability, University of Saskatchewan, 117 Science Place, Saskatoon, Saskatchewan S7N 5C8, Canada; phil.loring@usask.ca

${ }^{2}$ Department of Anthropology and Archaeology, and Sustainability Studies, University of Calgary, 2500 University Dr. NW, Calgary, Alberta T2N 1N4, Canada; scgerlac@ucalgary.ca

(C) The Arctic Institute of North America
} 


\section{INTRODUCTION}

Food security and insecurity are topics of increasing concern worldwide. Despite being extensively researched across the globe for nearly four decades, food security arguably remains a concept that is difficult to pin down in anything but the most general terms. On the other hand, food insecurity and hunger are more easily recognized; as of 2013, the United Nations Food and Agriculture Organization (FAO) reports that one in eight people in the world suffer from chronic hunger, that is, they do not get enough food to conduct an active and healthful life. In addition, at least as many people cope with a level of food insecurity that may be less extreme, but still affects their biophysical and psychological health (FAO, 2012, 2013). Overall, the number of undernourished people in the world is down $17 \%$ from two decades ago, though marked inequities persist among different regions of the world (FAO, 2013). In most cases, the people who are struggling with food insecurity are also at the front lines of the myriad challenges associated with anthropogenic climate change (O'Brien and Leichenko, 2000; IPCC, 2014).

The North American Arctic and Subarctic (hereafter, the North) is one such region of the world where food insecurity is a worsening problem and where the impacts of climate change are already extensive (CCA, 2014; IPCC, 2014). Accordingly, public awareness of food security challenges in the North has increased notably in the last few years, and this is evidenced by multiple national and international reports that highlight food insecurity among various other social, economic, and ecological challenges (Duhaime and Bernard, 2008; Meakin and Kurvits, 2009; CCA, 2014). In the most recent example, the Council of Canadian Academies released a report on the food security status of Aboriginal Canadians in the North, describing it as "a problem that requires urgent attention" (CCA, 2014:xiv). Northern food security has also received widespread media attention because of a string of food "crises" in Alaska linked to rising fuel and food prices and salmon fishery closures (Fazzino and Loring, 2009; Loring and Gerlach, 2010a). Additionally, northern peoples themselves are also raising public awareness of these challenges by telling their own stories via social media and in other venues (e.g., http:// www.feedingmyfamily.org/).

Given the urgency of food security as a widespread social problem, this paper aims to provide a synthesis of research on food security in the North. We first discuss early precursors to this research and show how research in the North has mirrored trends in food security research worldwide. Next, we report on our meta-analysis of the peer-reviewed literature on food security in the North, with attention to the questions asked, the methods employed, and the key themes and findings that have emerged. The research reveals much about the various social, economic, and ecological drivers and determinants that limit or enable Northerners to feed their families; however, the primary challenges are not solely the issues of environmental and climatic change that currently garner national and international headlines, but also long-standing issues related to governance, policy, and human rights. Although scholars have recognized food security as a primarily political issue for decades, and a number of policies now in place have the potential to protect the food security of northern peoples, many are still having trouble feeding their families. We present our review with an eye to future research that can address these apparent gaps between knowledge, policy, and action, and conclude with some suggestions for a rights-based approach to supporting a food-secure future for the people of the North.

\section{BACKGROUND ON FOOD SECURITY}

Food security, in the most general terms, means having reliable access to sufficient, safe, nutritious, and culturally preferred foods (FAO, 2008). Globally, nearly two billion people are not food-secure, and one in eight people worldwide experience chronic hunger - that is, they regularly do not have enough food to conduct an active life (FAO, 2013). Though food security is often misunderstood as a problem only in the "global South," a striking number of people in North America and particularly the North are also dealing with food insecurity, hunger, and multiple diet-related health problems (Snodgrass, 2013). A recent report shows that one in seven people in America relies on food assistance (Weinfeld et al., 2014). As of 2011 (the most recent year for which Statistics Canada has data), 12\% of Canadians are food insecure, and among Aboriginal households the rate can be much higher (Statistics Canada, 2013). In Nunavut, for example, rates from $36 \%$ to $68 \%$ have been reported (Rosol et al., 2011; CCA, 2014). Similarly in Alaska, at least $12.1 \%$ of households were food insecure as of 2012 (Coleman-Jensen et al., 2013), but as is true in Canada, Indigenous peoples bear a larger proportion of this burden. According to the non-profit organization Feeding America, up to $25 \%$ of households in some rural parts of the state experience food insecurity (Feeding America, 2013).

That food insecurity is an increasing problem in the North is to some extent surprising considering that a variety of legal protections exist at federal as well as state/provincial/territorial levels to ensure that residents of the North, who are by and large Indigenous people, can practice traditional subsistence practices. In Canada, the right to access country food has been ratified through multiple domestic and international agreements (Rideout et al., 2007), and access to country foods is further protected by the Constitution Act of 1982 and through the Canadian legal system's general recognition of Aboriginal title. In Alaska, where Aboriginal title has been extinguished by the Alaska Native Claims Settlement Act (Thériault et al., 2005), some protections still exist in the state constitution and state law. The constitution requires that fish and game resources be developed for the benefit of all Alaskans, and Alaska Statute 
16.05.258 also requires that people have reasonable opportunities for subsistence harvests, and that these harvests have priority over commercial and sport activities. At the federal level in the United States, laws such as the Alaska National Interests Lands Conservation Act and the Magnuson-Stevens Fishery Conservation and Management Act also require protections for access to subsistence foods and the sustainability of local communities.

Likewise, many government agencies are also attentive to the issue of food security in the North. At the federal level, both the U.S. Department of Agriculture and Health Canada produce regular assessments of household food security, and in Alaska, the Alaska Department of Fish and Game (ADF\&G) has assessed and reported on subsistence uses of country foods for decades (see Wheeler and Thornton, 2005 and citations therein) and more recently has also included assessments of household food security in its reports (e.g., Ikuta et al., 2014). This apparent disconnect between statutory protection and agency attention, on the one hand, and continuing decline in food security and dietrelated health outcomes, on the other, is among our primary motivations for this review.

Over the last half decade, the concept of food security has evolved significantly; although its origins are multifaceted, there is a clear connection with the 1974 World Food Conference in Rome, Italy, at which time the focus was on national security and the issue of securing global and statelevel food supplies to buffer against risk (Maxwell, 1996). In the decades that followed, the focus of people using the concept gradually shifted downscale, focusing instead on issues facing households, individuals, and livelihoods (Maxwell, 1996). This shift in focus is reflected in the ways people sought to measure or evaluate food security, which shifted from solely quantitative approaches that focused on food production and availability at national levels to more qualitative approaches that also incorporate food preferences and whether or not people worry about food (Maxwell, 2001). Additionally, the shift to a focus on livelihoods also moved the discourse away from describing food security as a condition that people do or do not have in favor of thinking about it as a process that people attempt to manage. Maxwell and Smith (1992:4) describe the process:

Flexibility, adaptability, diversification and resilience are key words. Perceptions matter. Intra-household issues are central. Importantly ... food security must be treated as a multi-objective process, where the identification and weighting of objectives can only be decided by the food insecure themselves.

Most recently, some food security research has returned its focus to world-scale aspects of the problem, such as globalization, population growth, and climate change (Ingram et al., 2010). However, most frameworks now aim to be interdisciplinary and strive to link the global with the local within a political ecology of three factors or dimensions of food security: availability of food, access to food, and food quality and utilization. Food availability refers to the amount, type, and quality of food a person or community has at its disposal, which may be analyzed in terms of the availability from local production, the efficiency of distribution networks for moving food from where it is produced or warehoused to where it needs to be, and the vulnerability of those distribution channels to supply and disruption. Food access, by comparison, refers to the ability of each person to procure the foods that are available, including physical and logistic access to the locations where foods can be procured, the affordability of foods, and how food allocation mechanisms such as subsidies, trade agreements, and other government policies work. Limits to access also involve any policy barriers, such as hunting and fishing regulations, that impede a person's ability to acquire foods that meet his or her sociocultural and biophysical food needs and preferences. This critical issue of sociocultural and biophysical needs also relates to the third dimension of food security, food quality and utilization, which refers to people's ability to derive all potential and needed benefits from the foods they have access to, including food safety, nutritional quality, and food consumption patterns and cultural preferences.

In research on the North, the concept of food security has followed an evolution similar to that described above, beginning with early, government-led and deficit-based approaches to food supply management, later shifting to place-based and qualitative approaches to understanding the relationships among people and their food, and now beginning to reorient around globally scaled drivers such as climate change. In early and mid-20th century Alaska, for example, the U.S. government was primarily concerned with the dietary adequacy and nutritional security of Alaska Natives. Perceiving their situation as dire and uncivilized, agencies such as the Bureau of Indian Affairs initiated targeted interventions such as reindeer herding and village-based gardening programs (Gerlach, 1996; Loring and Gerlach, 2010b). In the last few decades, the focus of research and of various intervention initiatives have shifted to focus on the right of Aboriginal peoples to feed themselves through preferred, customary, and traditional subsistence practices. Among the first and perhaps most important documents to mark this shift were two commissioned reports led by the Honorable Justice Thomas Berger of Canada. The first report examined the social and economic impacts of a proposed gas pipeline through the Mackenzie River Valley, and the second addressed the same issue for Aboriginal land-claim settlements in Alaska (Berger, 1977, 1985). While Justice Berger did not use the language of food security in these reports, he did make an argument in both regarding Aboriginal rights to pursue livelihoods centered on traditional harvests of fish and game and other uses of the land.

Similar arguments were also made by Hall et al. (1985), Wolfe and Walker (1987), and the National Research Council (2003), all with respect to Alaska Native land use, Aboriginal rights, restrictions on access to federal lands, and the 
possible impacts of land use and oil and natural gas development. Freeman (1997), Berardi (1998), Thornton (1998), and others also argued during this period for the protection of Aboriginal food systems and Aboriginal sovereignty over subsistence resources as a matter of livelihood security and cultural survival (see also several articles in volume 22.3 of Cultural Survival Quarterly, for which Thornton's article provides the introduction).

A second important body of literature addresses changing foodways in the North from the perspectives of nutrition and community health. Concerns about the health implications of the so-called "Western diet" for Indigenous peoples were raised as much as a century ago (Price, 1939), and in the North these changes to indigenous foodways were identified as impacts of colonization and industrial land development around the same time that Berger was critiquing such projects from a social justice perspective (Mann et al., 1962; Hurwitz, 1977; Schaefer et al., 1980). Concepts such as the "New World Syndrome" and the "nutrition transition" were coined as a shorthand for this transition from diets based on country food, or food from the land, which are understood to be of high nutritional quality, to lowerquality and increasingly expensive store-bought foods (Stephenson, 1995; Receveur et al., 1997; Kuhnlein et al., 2004). Of specific concern are a handful of related metabolic and cardiovascular syndromes and diseases, including Type 2 diabetes, coronary heart disease, and colorectal cancer (Mohatt et al., 2007). As we describe later, additional work in the last 15 years has extended our understanding of the health effects of this transition to include psychological and psychosocial impacts as well.

To our knowledge, the first major document to synthesize the various legal and biomedical issues found in these two streams of research within an explicit framework for food security is a book edited by Gerard Duhaime (2002), entitled Sustainable Food Security in the Arctic: State of Knowledge. In this work, food security is treated as a sustainable development goal: the volume proposes a systems-oriented framework for understanding how local community development can strengthen food security, one that is possibly the first to situate northern food security within the global economic and geopolitical system from the perspective of social-ecological systems. Rather than perpetuating a conceptual dichotomy between traditional and modern or Western practices, as we see in some earlier work, Duhaime and colleagues emphasize complex articulations among subsistence and Western economies and identify important dependencies, feedbacks, and interactions among such diverse issues as health, demography, production, distribution, access, and consumption. While the framework itself falls somewhat short of explicitly incorporating all of the qualitative aspects of food security that were being emphasized at the time for food security in other parts of the world (e.g., Maxwell, 2001), the individual chapters do emphasize self-governance and place-based strategies as essential pathways toward developing sustainable food security.

\section{Key Questions in Food Security Research}

Much high-quality research on food security in the North, published in both peer-reviewed and grey literatures, has followed from these earlier works. For the purposes of synthesis, we propose a typology of the research questions that food security research can address. Elsewhere, we and others have argued that food insecurity is best understood as a public health problem or syndrome (Power and Dietitians of Canada, 2005; Loring and Gerlach, 2009). We therefore identify four categories of research questions that mirror those found elsewhere in health research: phenomenology, epidemiology, etiology, and intervention (Kuller, 2007). It is important to note that these questions are not mutually exclusive, which means that studies may attend to more than one of the questions simultaneously.

1. What is food security? This area of research addresses phenomenological and paradigmatic aspects of food security. Research here acknowledges both objective and subjective dimensions of food security and asks how is it best defined and measured, and by whom. Of interest are the biomedical, psychological, social, cultural, and ecological dimensions of food security and insecurity.

2. Who is food secure/insecure? This is empirical research, including food security assessments and monitoring through demographic and epidemiological studies. Such studies often build on the data, hypotheses, or assumptions derived from work that addresses Question 1.

3. Why are people food secure/insecure? This research explores the etiology of food security - the social, political, and biogeographic drivers, from climate change to poverty-and also tests hypotheses that seek to explain the demographic and epidemiological patterns of food and nutritional insecurity identified by research addressing Question 2.

4. What solutions exist for improving food security? This research, which some might call applied, actionoriented, or intervention research, builds upon the data gleaned through the three previous questions to identify and implement food security intervention strategies. These typically include programs to address individuals' consumptive behaviors and preferences or their food production and procurement strategies. Also included here are questions of policy and how it may limit or enhance people's options for managing food security.

\section{METHODS}

This paper is a research synthesis (Mosteller and Colditz, 1996) that pairs the narrative, perspective-driven reading of the literature provided above with a structured metaanalysis focusing specifically on peer-reviewed publications. Meta-analysis is a method for research synthesis that is common in health research and is useful for identifying and summarizing key actionable issues and evidence, whether strong or weak, from a body of literature (Mosteller 
and Colditz, 1996; Cooper et al., 2009). One strength of meta-analysis here is that it enables us to explore answers to questions that are not or cannot be easily addressed by individual studies (Mosteller and Colditz, 1996). Specifically, meta-analyses have been used to explore disconnects between knowledge and action by focusing on the relative prevalence of research questions asked, trends in study design, if and how these have changed over time, and whether any notable gaps remain that require new research (Mosteller and Colditz, 1996).

For this meta-analysis we searched both Web of Science and Google Scholar on 7 March 2014 for peer-reviewed literature containing the search strings "food security" or "food insecurity" and "Arctic" or "Alaska" or "Canada" and excluded results not relating to North America and Arctic or Subarctic regions. No date range for publication was specified. We considered, but chose not to include such key words as "subsistence" or "country food" for a variety of reasons. One reason is that these key words also return a significant amount of literature on such varied topics as traditional knowledge, environmental change, and indigenous rights and sovereignty. Many of these topics are important to food security, but they do not, on their own, represent food security research as categorized above. Drawing an analogy to health research, had our meta-analysis focused on metabolic syndrome rather than food security, it would have been similarly inappropriate to include papers that focus only on the problem of high cholesterol or physical activity without including the syndrome as an explicit integrative framework. Further, had we chosen to include research on subsistence, we would have been compelled to include research on sport fishing, agriculture, reindeer herding, and so on. For any meta-analyses to be informative, it is essential that the boundaries be clearly defined and circumscribed.

Not all papers found via this search were guaranteed to be included in our final analysis. For example, we included only papers found in the first 10 pages of results from Google Scholar. We excluded conference abstracts and commentaries or editorials in peer-reviewed venues unless they specifically presented some framework for understanding or responding to food security in the North that had not been published elsewhere. Papers that do not address at least one of the research questions noted above were excluded; for example, we excluded studies of nutrition and toxicology unless these were discussed in conjunction with food security or food system transitions. We also excluded publications that address food security at global or national levels but do not explore issues specific to the North in more than passing detail.

We debated about including grey literature in this metaanalysis, but ultimately chose not to do so, a decision that is common but that has also been contested by some as possibly introducing a source of bias (Cooper et al., 2009). Our intent is not to marginalize this literature, much of which we refer to above in the narrative portion of our synthesis and regularly use in our own research on northern food systems. A justification for not including this literature is methodological; criteria for inclusion in meta-analysis need to be consistent and reproducible, but much of the grey literature on food security is embedded within lengthy agency reports that focus primarily on subsistence practices during a particular time frame, and deciding which of these to include would introduce a subjective dimension to our study. The more important question, however, is whether inclusion of this literature would change our overall findings, and here we argue that it would not - that the peerreviewed literature provides an accurate indicator of the present state of research and knowledge on food security in the North. We frequently encounter peer-reviewed documents that cite multiple grey sources, and in our experience cross-pollination among agency and academic practitioners in the North is extensive. Further research might contest this assumption, and exploring any differences among these bodies of literature to evaluate the implications for science, policy, and practice could be a fruitful research avenue for a different paper.

We coded publications deductively by their relationship to the four research questions identified above and also by whether they identify issues of availability, access, or food quality or utilization. We also coded the documents inductively for major themes or ideas (e.g., climate change, gender, vulnerability), whether or not they employed a participatory methodology, and whether they provide conceptual frameworks or report on qualitative methods, quantitative methods, research synthesis (reviews and meta-analyses), or critique.

\section{RESULTS}

Our search yielded 62 peer-reviewed documents published between 1997 and 2013 (see online Appendix 1 for a complete list). The number of publications per year has grown notably, from one paper each in 1997, 2004, and 2005 to an average of 11 papers per year since 2010 (Fig. 1). Most of that growth is accounted for by increases in papers addressing Questions 2 to 4. Indeed, Question 1 is addressed in only eight papers; in 2007 and 2008, three of the four papers published focused primarily on the question of how to best define and measure food security. Attention to specific social and ecological drivers of food security (Question 3) has been ubiquitous in the last 15 years, but has leveled off in the last few years. Meanwhile, research focusing on intervention has grown since 2009; in the early years, such papers primarily addressed policy interventions necessary for supporting Aboriginal rights, whereas in recent years, intervention research has focused more on consumer behavior and nutritional intervention. Note that while they were excluded from further analysis, three published conference abstracts were also identified for 2013 that describe designs for food security intervention programs, further emphasizing the increase of interest in this area. 


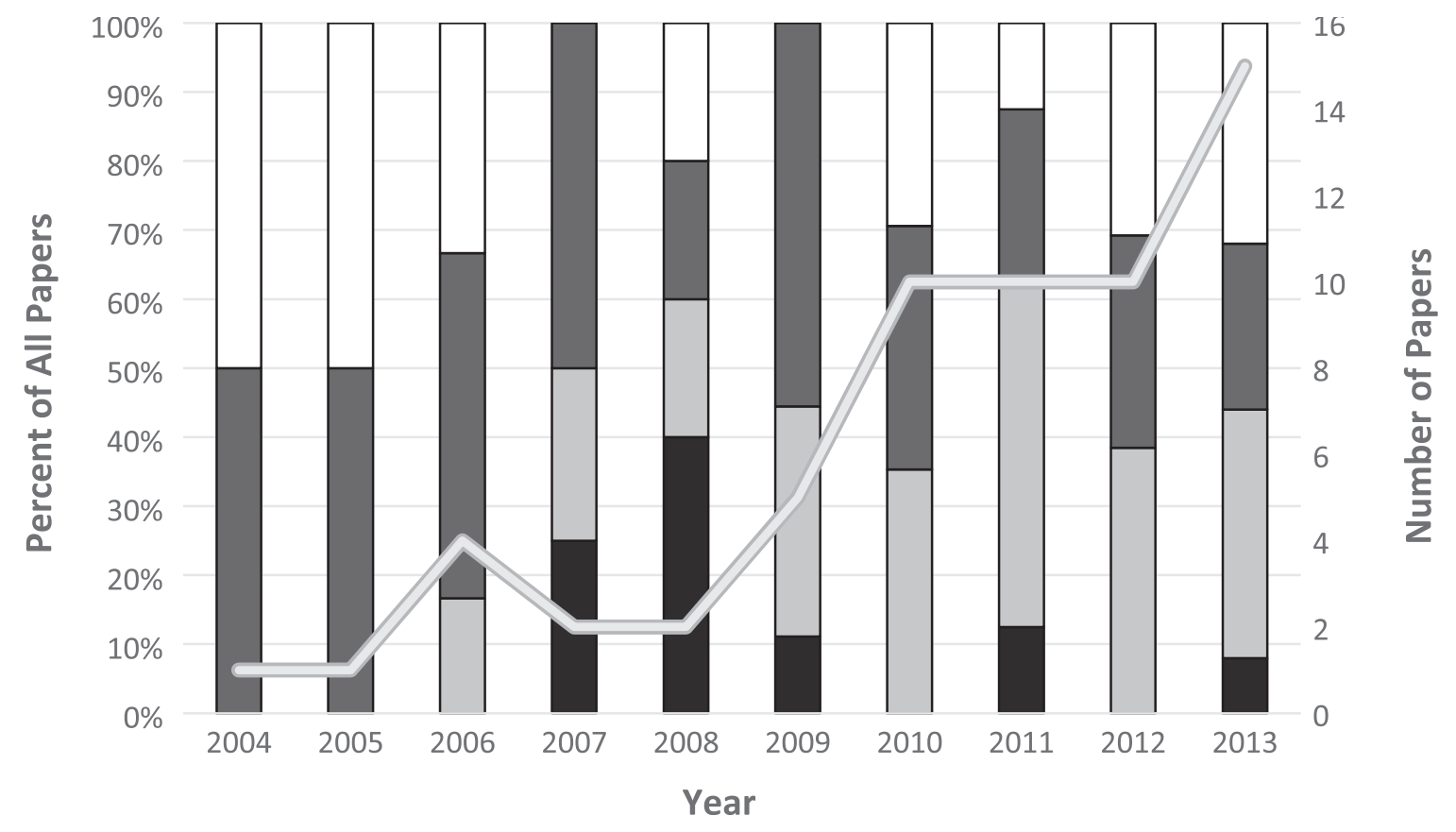

Phenomenology $\square$ Epidemiology $\square$ Etiology $\square$ Intervention

\section{Paper Count}

FIG. 1. Number of papers on food security and percentage of papers dealing with each of the four main factors (phenomenology, epidemiology, etiology, and intervention) for each year from 2004 to 2013 . At least $20 \%$ of papers regularly focused on etiology of food security, though this emphasis has declined; focus has seemingly shifted to epidemiology (assessment). Focus on interventions has been mostly stable over the years, while research addressing phenomenological aspects of the problem has remained sparse.

As noted, we coded the documents according to the dimension(s) of food security they address: availability, access, and quality or utilization. Access was the most commonly discussed issue (26 papers), and barriers described range from economic to land tenure and hunting and fishing regulations. Quality and utilization were raised by 18 papers, with regard to such issues as methylmercury, persistent organic pollutants, food spoilage, and cultural preference for specific foods. Discussion of food availability increased by 12 papers, most often with respect to the impacts of climate change on fish and game populations, but notably, 7 of the 12 raised the issues of access and availability together.

The frequency with which publications address other key issues or themes in food security research varies notably. The vast majority, 50 papers, focus on rural issues, while only three attempt to link rural and urban or local and global systems, as argued in Duhaime (2002). Likewise the papers retrieved through this search more often emphasize subsistence or country foods (36 papers), compared to the 12 that discuss market foods. Environmental and climatic changes are raised in 20 papers and health or nutrition in 22 , but comparatively few papers address policy (7), gender (6), natural resource development (3), and social or environmental justice (8). Notably, there are no papers in this literature that focus specifically on food production (i.e., agriculture). Geographically, 45 papers focus on Canada's North, compared to 23 focusing on Alaska, and only six papers discuss both regions.

Qualitative research dominates the food security literature on the North (28 papers), including diverse methods that range from photo-voice to structured interviews and focus groups. Nine papers employ exclusively quantitative methods, and another four employ both. Ten papers are reviews, 11 are critiques, and eight provide frameworks for research, synthesis, or policy. Also of interest is that only nine of the 62 papers adopt participatory methods.

From these 62 papers, we have identified several common ideas and findings regarding food security in northern North America. First, four key factors contributing to food security or insecurity emerge. Note that citations in the following section are only examples, not a comprehensive list (see Appendix 1).

\section{Key Factors Contributing to Food Security}

1. Over-Connectedness to the Global System: Subsistence activities in the North are largely dependent on expensive technology (e.g., motorboats, all-terrain vehicles, and snowmobiles), and with these comes reliance on gasoline and other supplies and equipment. Many papers have explored the impacts of high and rising costs of fuel 
in the remote North, with local people reporting that it has caused them to both reduce the number of trips they take for harvest purpose, and to shorten the length of those trips (Lambden et al., 2006; Ford, 2009). A related issue is the high and rising costs of store-bought foods, which create various double-bind (lose-lose) scenarios for northern peoples such as decisions between buying food or heating one's home, or reallocating time toward cash employment and away from subsistence activities (Fazzino and Loring, 2009; Skinner et al., 2014).

2. Impacts of Contaminants and Pathogens on the Quality of Subsistence Foods: Much research has been done on the health risks of contaminants, pollutants, and pathogens affecting subsistence species in the North, including contaminants in fish (Loring et al., 2010), marine mammals (Gadamus, 2013), and caribou (Schuster et al., 2011). Food safety is also being compromised in some communities because of the impacts of climate warming on traditional food storage cellars, and because of changing knowledge about food storage, moving away from traditional techniques to the use of plastic garbage sacks, Tupperware $^{\mathrm{TM}}$, and other containers that are inadequate and unsafe for long-term food storage (Brubaker et al., 2011).

3. Climatic and Environmental Change Impacts on Hunting, Fishing, and Gathering Practices: Multiple papers address the direct and indirect impacts of climatic and environmental change on subsistence practices, including impacts on the distribution and abundance of fish and game species (Loring and Gerlach, 2010a; Wesche and Chan, 2010), on land and seascape conditions (Guyot et al., 2006; Ford, 2009), and on the safety of hunters and fishers (Wesche and Chan, 2010; Brubaker et al., 2011).

4. Management and Governance Constraints: While the availability of wild fish and game are issues discussed in many papers, barriers to access created by economics or existing governance and policy regimes emerge as the most commonly raised issue for food security in the region. For example, while climate change is no doubt a challenge, northern peoples have historically been able to respond effectively to changes in the land and seascapes and to the distribution of fish and game through flexible and adaptive subsistence strategies. The research reviewed here highlights how governance and management structures can limit people's options and flexibility in this regard-restrictive land tenure regimes, and hunting and fishing seasons that are increasingly out of sync with changing seasonality and phenology of fish and game are two examples (Loring and Gerlach, 2010a; McNeeley, 2012; Gadamus, 2013).

\section{Key Theoretical Ideas}

1. History Matters: The papers we reviewed provide exceptional detail about environmental and economic dimensions of food security and insecurity in the North, and how the downscale impacts of these drivers are mediated by the social and ecological legacies of colonialism and federal land-claim settlement. Ford et al. (2012:1) argue that food security "must be understood in the context of socioeconomic transformations that have affected Inuit society over the last half century as former semi-nomadic hunting groups were resettled into permanent settlements." Similarly, Fazzino and Loring (2009:153) argue that understandings of food security in the North need to "highlight [both] the geographic and temporal continuity of failed food systems," as opposed to focusing only on the most recent or highest profile elements of crises that befall northern peoples. Likewise, Fieldhouse and Thompson (2012) talk about the various social and structural barriers to accessing sufficient healthy food that northern people face, barriers such as poverty, social exclusion, and economic marginalization.

2. Demographics Matter: Food insecurity is experienced differently by different people, even at the sub-household level. Specifically, there is evidence in this review that women and children in the North are most vulnerable to food systems disruptions. In a 2010 study of Inuit preschoolers in Nunavut, for example, nearly $70 \%$ were found to live in a food-insecure household (Egeland et al., 2010). Likewise, single and widowed women often have limited access to traditional foods, and this despite a widespread culture of food sharing (Beaumier and Ford, 2010).

3. Food Security is Both a Condition and a Process: Some papers in this review caution that quantitative dietary assessments provide a limited window into more complex local and regional systems and strategies for food procurement, and highlight the importance of social networks, food sharing, food preservation strategies, and co-management of resources (Ford, 2009; Harder and Wenzel, 2012; Gadamus, 2013). The embedded argument in these papers is that while many people in the North no doubt lack reliable access to high quality and preferred foods, food security must also be understood as an ongoing process by which people negotiate needs, preferences, and vulnerabilities within the context of economic and environmental variability and change (Ford, 2009; Loring and Gerlach, 2009).

4. Flexibility and Diversity are Essential: A corollary to the previous observation that is also encountered in this literature is that flexibility and diversity are properties of food systems that can improve food security in the North. This proposition is only argued indirectly, however, in that the authors observe and critique existing limits to flexibility and diversity, such as land tenure restrictions on where people can hunt, as being detrimental to food security (Loring and Gerlach, 2009; McNeeley, 2012). No research was identified in this review that quantitatively links positive food security outcomes with high flexibility or diversity in the food system.

5. Access to Local Food Improves Food Security: Our review identifies two studies that show a positive relationship between household food security and access to local fish and game resources, whether through direct harvesting opportunities or through sharing, barter, and trade (Ford and Berrang-Ford, 2009; Loring et al., 2013a). It is often assumed or argued in the literature on food systems that access to locally produced and procured foods improves 
food security. The implication for the North is that traditional foodways have the potential to serve as the foundation of solutions for food security in the North if other barriers are addressed.

6. Food, Culture, Human Health, and Ecosystem Health are Interrelated: As noted earlier, agencies, academics, and policymakers have revised and modified their definitions of food security over the last few decades, from simplistic ledgers of calories and nutrients to place-based assessments that take into account the cultural importance of certain foods and the many roles that food and foodways play in people's lives. Much research on the North is at the forefront of this argument. Loring and Gerlach (2009), for example, argue for an integrated, social-epidemiological approach to food security that links biophysical, psychological, psychosocial, and sociocultural dimensions of food systems. Similarly, Gadamus (2013) describes direct and indirect reciprocal relationships among ecosystem health, food security, and human health in the North.

\section{DISCUSSION}

Early writings on food security in the North emphasized the social underpinnings of the problem, specifically, a lack of legal protections for indigenous territorial sovereignty and subsistence practices. Coming full circle, we argue that the literature of the last 15 years or so continues to illustrate that food security in the North remains primarily a social and political rather than a biogeographic or ecological problem. In other words, the problem is not that adequate healthy foods are not available, but that people do not enjoy consistent and reliable access to these foods, whether we are speaking of food from the land or food from the market. While there is no doubt that climate change and the unique circumstances of living in the North (such as long supply chains and limits to agriculture) play a role, they only serve to exacerbate more fundamental drivers: top-down governance structures, policies regarding land use and resource management that are not sufficiently flexible or responsive to rapid environmental change, and economic development agendas that marginalize the rights and needs of Indigenous peoples. These drivers also have an important historical dimension; Indigenous peoples in the North are largely locked in to what can be called "manufactured insecurity" (see Eichelberger, 2011) - that is, they are less mobile as a result of being forced to live in fixed villages and are locked in from flexibility and adaptability by land tenure, wildlife management regimes, and the high costs of food, fuel, and supplies (Berardi, 1998; Gerlach et al., 2011; Brinkman et al., 2014).

The issue of anthropogenic climate change provides an informative example of why a focus on social issues such as rights and governance should remain the priority for those working to improve food security in the North. Brigham and colleagues (AMSA, 2009) offer four scenarios for the future of the Arctic (Fig. 2) based on future demand for Arctic resources and the stability of Arctic governance:
1) "Arctic Race," in which ad hoc and poorly developed governance does not keep up with the high demand for Arctic resources, resulting in a gold-rush approach; 2) "Arctic Saga," in which high demand is tempered by stable governance structures, leading to development balanced with the needs of local peoples and ecosystems; 3) "Polar Lows," in which demand does not materialize and limited governance leads to little change or development for the region; and 4) "Polar Preserve," in which stable governance pursues extensive protection of Arctic ecosystems and peoples without external geopolitical pressure.

Extensive evidence indicates that climate change will continue to pose multiple challenges for the North and that many national and international players have adopted an attitude of acquiescence to those impacts, emphasizing economic development opportunities over social and environmental justice concerns (Loring, 2013a; Loring and Fazzino, 2014). Therefore, we argue that only the two highdemand scenarios identified by Brigham and colleagues (AMSA, 2009) are now likely: Arctic Race and Arctic Saga. Of these, the latter would ensure a thriving and foodsecure future for Arctic peoples, but the former scenario, an extreme example of which is provided by the environmental degradation and injustice found in the Niger River Delta, seems more likely, given that existing legal protections for indigenous rights already fail to ensure regional food security. Ideas for strengthening self-governance in the North, therefore, need to see beyond past concepts such as adaptation and resilience and look instead to rights-based reform around concepts such as food sovereignty, which implies the right of people to control their food supply (Via Campesina, 1996).

An example from the fisheries sector in Alaska is informative regarding how changes to governance could move the system in the direction of an "Arctic Saga" scenario by improving food security without necessarily compromising the economic development of resources in the region. As noted above, the Alaska constitution and other laws require that fish and game in the state be managed for the "maximum benefit" of Alaskans and with priority given to personal uses. Nevertheless, many Alaskans remain vulnerable in the shadow of these laws; in some cases, commercial fisheries have been opened while subsistence fisheries were closed, and in the case of declared fisheries failures, financial support is available only to those engaged in commercial fisheries (Loring and Gerlach, 2010a). Likewise, distributional equity in Alaska's fisheries is limited by solely economic interpretations of the "maximum benefit" clause and by strict policy delineations between commercial, sport, and subsistence fisheries that do not reflect the blended nature of local fishing practices (Carothers, 2010; Loring, 2013b; Loring et al., 2013a). An alternative, however, would be to interpret the maximum benefit clause as a mandate for food security or even food sovereignty. Under such a mandate, the state could create an artisanal tier of fisheries-fisheries that blend personal and commercial uses and provide a venue for both expanding fishing rights 


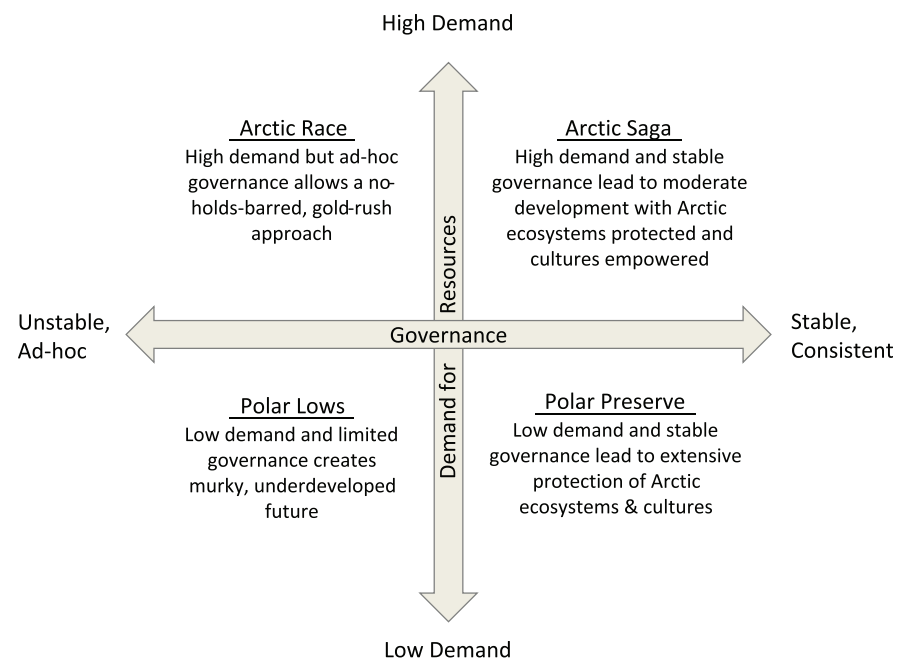

FIG. 2. Four scenarios for the future of the Arctic. Adapted from AMSA (2009).

among Alaskans and prioritizing local markets for locally caught seafood.

This is just one hypothetical solution, and we recognize that such solutions are contingent on whether policymakers in the United States and Canada are willing to recognize, prioritize, and enforce the rights of Indigenous peoples and other local residents. These include the right to be in control of development, as set out for example in the United Nations Declaration on the Rights of Indigenous Peoples, and also the basic human right to food, as set out in the UN's Universal Declaration of Human Rights. A question is how effective local and regional efforts to secure food security can ultimately be if governments do not take steps to recognize these rights, as is the case in the United States (Chilton and Rose, 2009), or to enforce these rights once recognized, which evidence suggests is the case in Canada (Rideout et al., 2007). We have the policies and the tools and the toolkit, conceptual and methodological, to improve urban and rural food security in the North, but do we have the political will to do so?

\section{Future Research}

A few areas of research in need of further attention also emerge from our meta-analysis. At present there is limited research addressing rural-urban linkages and the global geopolitical and economic drivers and determinants of food insecurity in the North, namely, extractive resource development and global markets and supply chains for food and fuel. However, new research frameworks are emerging in the international food security literature that can address these local-global interdependencies more directly. We specifically highlight "nexus" research, an initiative that focuses on the interactions among food security, water security, energy security, and human health (Bizikova et al., 2013; Loring et al., 2013b). Nexus research recognizes that food, water, energy, and health have complex relationships that are not easily disentangled. In the North, research at this nexus would be valuable for both looking back at the historical legacies of past development and looking forward to the impacts of future changes. Ideally, solutions for strengthening food, water, and energy security and health can be mutually supportive; that is, solutions in one area need not create compromises or impacts on others. In practice, however, tradeoffs, such as those between food security and offshore drilling or other industrial development activities such as mining, appear to be unavoidable. Assuming that both water and energy security, like food security, have important place-based features as we discuss above, the resulting heterogeneous landscape of systems and solutions for food, water, and energy is sure to involve conflicts and trade-offs that, while perhaps not easily resolved, can at least be managed effectively if the authority to do so is situated at the appropriate levels of social and political organization, and at the appropriate spatial and temporal scales.

The relative lack of community-based participatory research (CBPR) and other participatory approaches encountered in our meta-analysis is perhaps the most notable area where food security research in the North is less robust than we would have expected, especially considering our discussion of rights-based approaches above and despite increasing attention in academia and policymaking in general to CBPR and to indigenous research methods. We also noted a relative lack in recent years of research that pursues place-based definitions and understandings of food security (i.e., Question 1). This gap in the research is noteworthy; approaches to CBPR such as participatory and mediated health planning have proven to be an effective way to answer research questions and also empower people in a "citizen politics" arena to develop place-based solutions to problems such as food insecurity (McCullum et al., 2002; Salem, 2005). Furthermore, participatory approaches can create space for other neglected yet important and related topics in food security research to receive attention, topics such as gender, domestic violence, natural resource development, and rural-urban linkages (HayesConroy and Sweet, 2014). Participatory projects require long-term commitments and relationships among researchers and community members, and they are often successful in bringing together people with diverse interests to "build a shared understanding of a problem and envision workable solutions" (McCullem et al., 2002:966). Even the ability to define the problem on one's own terms represents in many places a move away from the status quo (Checker, 2007).

The research by the Center for Alaska Native Health Research on nutritional security in Northwest Alaska (Mohatt et al., 2007) that we cited earlier is a noteworthy example of CBPR in the North, and one where we know by experience that the tenure and impacts of their work far supersedes that which is represented in the peer-reviewed literature. This again raises the importance of recognizing that while peer-reviewed literature provides a window into the state of knowledge regarding food security in the North, it may provide a less-than-complete picture regarding the state of practice. 
If food security is to be solved as a matter of power and human rights, as we suggest, it follows that solutions must be developed from the ground up, and we know of multiple community-based and community-led projects underway under the auspices of food policy councils, tribal organizations, or other local agencies that are working in this direction. As just one additional example, the Alaska office of the Inuit Circumpolar Council is currently engaged in a new research initiative on northern food security, a project that may provide an exemplar for how to do this sort of work elsewhere in the Arctic and in other parts of the world. A remaining question that we have, however, is how to entrain these studies and their findings into the political discourse and policymaking process so that people's voices are empowered and their ideas implemented. Unfortunately, awareness of food security as a public health and social justice issue has not to date been sufficient to change the way that development and the future of the Arctic's landscapes and seascapes are discussed by those in power. It often takes a crisis or trauma to generate the political will necessary for fundamental societal change in how environmental issues are perceived (Pelling and Dill, 2009). Our hope, however, is that further participatory research that establishes the fundamental linkages among human health, ecosystem health, and social justice, and which shows definitively that addressing social problems like poverty and food insecurity is part and parcel of achieving ecological sustainability, can illuminate a path toward change that does not entail unnecessary human costs.

\section{ACKNOWLEDGEMENTS}

This work is a part of the Sustainable Futures North program, funded by a grant from the National Science Foundation Arctic Science, Education, and Engineering for Sustainability (Arctic SEES) (grant \#1263853) and from the National Oceanic and Atmospheric Administration's Climate-Society Interactions program (grant \#NA11OAR4310135). We thank Alysa Loring, the editor, and the two anonymous reviewers for their input. With this article we also honor the memory of Chief Patrick Smith of Minto, Alaska, an important advocate for food security in the North who contributed much to our work over the years.

\section{APPENDIX 1.}

A list of papers retrieved in the meta-analysis is available as a supplementary file to the online version of this article at: http://arctic.journalhosting.ucalgary.ca/arctic/index.php/arctic/rt/ suppFiles/4509/0

\section{REFERENCES}

AMSA. 2009. Arctic marine shipping assessment 2009 report. Tromsø, Norway: Arctic Council.
Beaumier, M.C., and Ford, J.D. 2010. Food insecurity among Inuit women exacerbated by socio-economic stresses and climate change. Canadian Journal of Public Health 101(3):196-201.

Berardi, G. 1998. Natural resource policy, unforgiving geographies, and persistent poverty in Alaska Native villages. Natural Resources Journal 38(1):85-108.

Berger, T.R. 1977. Northern frontier, northern homeland: The report of the Mackenzie Valley Pipeline Inquiry. Ottawa, Ontario: Minister of Supply and Services Canada.

- 1985. Village journey: The report of the Alaska Native Review Commission. New York: Hill \& Wang.

Bizikova, L., Roy, D., Swanson, D., Venema, H.D., and McCandless, M. 2013. The water-energy-food security nexus: Towards a practical planning and decision-support framework for landscape investment and risk management. Winnipeg, Manitoba: International Institute for Sustainable Development.

Brinkman, T., Maracle, K.B., Kelly, J., Vandyke, M., Firmin, A., and Springsteen, A. 2014. Impact of fuel costs on high-latitude subsistence activities. Ecology and Society 19(4): 18. http://dx.doi.org/10.5751/ES-06861-190418

Brubaker, M.Y., Bell, J.N., Berner, J.E., and Warren, J.A. 2011. Climate change health assessment: A novel approach for Alaska Native communities. International Journal of Circumpolar Health 70(3):266-273. http://dx.doi.org/10.3402/ijch.v70i3.17820

Carothers, C. 2010. Tragedy of commodification: Displacements in Alutiiq fishing communities in the Gulf of Alaska. Mast 9(2):95-120.

CCA (Council of Canadian Academies). 2014. Aboriginal food security in northern Canada: An assessment of the state of knowledge. Ottawa, Ontario: CCA.

Checker, M. 2007. "But I know it's true:" Environmental risk assessment, justice, and anthropology. Human Organization 66(2):112-124.

Chilton, M., and Rose, D. 2009. A rights-based approach to food insecurity in the United States. American Journal of Public Health 99(7):1203-1211. http://dx.doi.org/10.2105/AJPH.2007.130229

Coleman-Jensen, A., Nord, M., and Singh, A. 2013. Household food security in the United States in 2012. Economic Research Report 155. Washington, D.C.: United States Department of Agriculture, Economic Research Service.

http://www.ers.usda.gov/publications/err-economic-researchreport/err155.aspx\#.U2vpwfldXpp

Cooper, H., Hedges, L.V., and Valentine, J.C., eds. 2009. The handbook of research synthesis and meta-analysis, $2^{\text {nd }}$ ed. New York: The Russell Sage Foundation.

Duhaime, G. 2002. Sustainable food security in the Arctic: State of knowledge. Occasional Publication Series 52. Edmonton, Alberta: CCI Press.

Duhaime, G., and Bernard, N., eds. 2008. Arctic food security. Edmonton, Alberta: CCI Press; Québec City, Québec: CIÉRA.

Egeland, G.M., Pacey, A., Cao, Z., and Sobol, I. 2010. Food insecurity among Inuit preschoolers: Nunavut Inuit child health survey, 2007-2008. Canadian Medical Association Journal 182(3):243-248. http://dx.doi.org/10.1503/cmaj.091297 
Eichelberger, L.P. 2011. Manufacturing insecurity: Power, water, waste, and the silences of sustainability and suffering in Northwest Alaska. PhD thesis, University of Arizona, Tempe, Arizona.

FAO (Food and Agriculture Organization of the United Nations). 2008. An introduction to the basic concepts of food security. Rome: FAO. http://www.fao.org/docrep/013/a1936e/a1936e00.pdf

- 2012. The state of food insecurity in the world 2012: Economic growth is necessary but not sufficient to accelerate reduction of hunger and malnutrition. Rome: FAO. http://www.fao.org/docrep/016/i3027e/i3027e00.htm

- 2013. The state of food insecurity in the world 2013: The multiple dimensions of food security. Rome: FAO. http://www.fao.org/docrep/018/i3434e/i3434e00.htm

Fazzino, D.V., and Loring, P.A. 2009. From crisis to cumulative effects: Food security challenges in Alaska. NAPA Bulletin 32(1):152-177. http://dx.doi.org/10.1111/j.1556-4797.2009.01033.x

Feeding America. 2013. Map the meal gap: Food insecurity rates. Chicago: Feeding America.

http://feedingamerica.org/hunger-in-america/hunger-studies/ map-the-meal-gap.aspx

Fieldhouse, P., and Thompson, S. 2012. Tackling food security issues in indigenous communities in Canada: The Manitoba experience. Nutrition \& Dietetics 69(3):217-221. http://dx.doi.org/10.1111/j.1747-0080.2012.01619.x

Ford, J.D. 2009. Vulnerability of Inuit food systems to food insecurity as a consequence of climate change: A case study from Igloolik, Nunavut. Regional Environmental Change 9(2):83-100. http://dx.doi.org/10.1007/s10113-008-0060-x

Ford, J.D., and Berrang-Ford, L. 2009. Food security in Igloolik, Nunavut: An exploratory study. Polar Record 45(3):225-236. http://dx.doi.org/10.1017/S0032247408008048

Ford, J., Lardeau, M.-P., and Vanderbilt, W. 2012. The characteristics and experience of community food program users in Arctic Canada: A case study from Iqaluit, Nunavut. BMC Public Health 12(1): 464. http://dx.doi.org/10.1186/1471-2458-12-464

Freeman, M.M.R. 1997. Issues affecting subsistence security in Arctic societies. Arctic Anthropology 34(1):7-17.

Gadamus, L. 2013. Linkages between human health and ocean health: A participatory climate change vulnerability assessment for marine mammal harvesters. International Journal of Circumpolar Health 72(S1): 20715.

http://dx.doi.org/10.3402/ijch.v72i0.20715

Gerlach, S.C. 1996. Historical archaeology and the early twentieth century reindeer herding frontier on the northern Seward Peninsula, Alaska. In: Schaaf, J., and Smith, T., eds. Ublasaun, first light: Inupiaq hunters and herders in the early twentieth century, northern Seward Peninsula, Alaska. Fairbanks: U.S. Department of the Interior, National Park Service. 95-98.
Gerlach, S.C., Loring, P.A., Turner, A.M., and Atkinson, D.E. 2011. Food systems, climate change, and community needs. In: Lovecraft, A.L., and Eicken, H., eds. North by 2020: Perspectives on Alaska's changing social-ecological systems. Fairbanks: University of Alaska Press. 111-134.

Guyot, M., Dickson, C., Paci, C., Furgal, C., and Chan, H.M. 2006. Local observations of climate change and impacts on traditional food security in two northern Aboriginal communities. International Journal of Circumpolar Health 65(5):403-415. http://dx.doi.org/10.3402/ijch.v65i5.18135

Hall, E.S., Jr., Gerlach, S.C., and Blackman, M.B. 1985. In the national interest: A geographically based study of Anaktuvuk Pass Iñupiat subsistence through time. Barrow, Alaska: North Slope Borough.

Harder, M.T., and Wenzel, G.W. 2012. Inuit subsistence, social economy and food security in Clyde River, Nunavut. Arctic 65(3):305-318. http://dx.doi.org/10.14430/arctic4218

Hayes-Conroy, A., and Sweet, E.L. 2014. Whose adequacy? (Re) imagining food security with displaced women in Medellín, Colombia. Agriculture and Human Values. http://dx.doi.org/10.1007/s10460-014-9546-y

Hurwitz, B. 1977. Subsistence foods: A physician's perspective on the $\mathrm{d} 2$ land proposal. Alaska Medicine 19(5):60-66.

Ikuta, H., Brown, C.L., and Koster, D.S. 2014. Subsistence harvests in 8 communities in the Kuskokwim River drainage and lower Yukon River, 2011. Technical Paper No. 396. Fairbanks: Alaska Department of Fish and Game, Division of Subsistence.

Ingram, J., Ericksen, P., and Liverman, D., eds. 2010. Food security and global environmental change. London: Earthscan.

IPCC (Intergovernmental Panel on Climate Change). 2014. Climate change 2014: Impacts, adaptation, and vulnerability. IPCC Working Group II contribution to the Fifth Assessment Report. Geneva, Switzerland: IPCC.

Kuhnlein, H.V., Receveur, O., Soueida, R., and Egeland, G.M. 2004. Arctic indigenous peoples experience the nutrition transition with changing dietary patterns and obesity. Journal of Nutrition 134(6):1447-1453.

Kuller, L. 2007. Is phenomenology the best approach to health research? American Journal of Epidemiology 166(10):1109-1115.

http://dx.doi.org/10.1093/aje/kwm258

Lambden, J., Receveur, O., Marshall, J., and Kuhnlein, H.V. 2006. Traditional and market food access in Arctic Canada is affected by economic factors. International Journal of Circumpolar Health 65(4):331-340.

http://dx.doi.org/10.3402/ijch.v65i4.18117

Loring, P.A. 2013a. Are we acquiescing to climate change? Social and environmental justice considerations for a changing Arctic. In: Mueter, F.J., Dickson, D.M.S., Huntington, H.P., Irvine, J.R., Logerwell, E.A., MacLean, S.A., Quakenbush, L.T., and Rosa, C., eds. Responses of Arctic marine ecosystems to climate change. Fairbanks: Alaska Sea Grant, University of Alaska Fairbanks. 1-11.

http://dx.doi.org/10.4027/ramecc.2013.01 
2013b. Alternative perspectives on the sustainability of Alaska's commercial fisheries. Conservation Biology 27(1):55-63.

http://dx.doi.org/10.1111/j.1523-1739.2012.01938.x

Loring, P.A., and Fazzino, D.V., II. 2014. From "would" and "will" to "could" and "can": Climate change and environmental (in) justice in the North American Arctic. Anthropology News, April.

http://dev.aaanet.org/index.php/2014/04/30/from-would-andwill-to-could-and-can/

Loring, P.A., and Gerlach, S.C. 2009. Food, culture, and human health in Alaska: An integrative health approach to food security. Environmental Science \& Policy 12(4):466-478. http://dx.doi.org/10.1016/j.envsci.2008.10.006

- 2010a. Food security and conservation of Yukon River salmon: Are we asking too much of the Yukon River? Sustainability 2(9):2965-2987. http://dx.doi.org/10.3390/su2092965

- 2010b. Outpost gardening in Interior Alaska: Food system innovation and the Alaska Native gardens of the 1930s through the 1970s. Ethnohistory 57(2):183-199. http://dx.doi.org/10.1215/00141801-2009-060

Loring, P.A., Duffy, L.K., and Murray, M.S. 2010. A risk-benefit analysis of wild fish consumption for various species in Alaska reveals shortcomings in data and monitoring needs. Science of the Total Environment 408(20):4532-4541. http://dx.doi.org/10.1016/j.scitotenv.2010.07.013

Loring, P.A., Gerlach, S.C., and Harrison, H.L. 2013a. Seafood as local food: Food security and locally caught seafood on Alaska's Kenai Peninsula. Journal of Agriculture, Food Systems, and Community Development 3(3):13-30. http://dx.doi.org/10.5304/jafscd.2013.033.006

Loring, P.A., Gerlach, S.C., and Huntington, H.P. 2013b. The new environmental security: Linking food, water, and energy for integrative and diagnostic social-ecological research. Journal of Agriculture, Food Systems, and Community Development 3(4):55-61. http://dx.doi.org/10.5304/jafscd.2013.034.005

Mann, G.V., Scott, E.M., Hursh, L.M., Heller, C.A., Youmans, J.B., Consolazio, C.F., Bridgforth, E.B., et al. 1962. The health and nutritional status of Alaskan Eskimos: A survey of the Interdepartmental Committee on Nutrition for National Defense-1958. The American Journal of Clinical Nutrition 11(1):31-76.

Maxwell, S. 1996. Food security: A post-modern perspective. Food Policy 21(2):155-170. http://dx.doi.org/10.1016/0306-9192(95)00074-7

- 2001. The evolution of thinking about food security. In: Devereux, S., and Maxwell, S., eds. Food security in subSaharan Africa. London: ITDG. 13-31. http://dx.doi.org/10.3362/9781780440170.002

Maxwell, S., and Smith, M. 1992. Household food security: A conceptual review. In: Maxwell, S., and Frankenberger, T.R., eds. Household food security: Concepts, indicators, measurements. A technical review. New York: UNICEF; Rome: IFAD. 1-72.

http://www.ifad.org/hfs/tools/hfs/hfspub/hfs.pdf
McCullum, C., Pelletier, D., Barr, D., and Wilkins, J. 2002. Use of a participatory planning process as a way to build community food security. Journal of the American Dietetic Association 102(7):962-967.

http://dx.doi.org/10.1016/S0002-8223(02)90220-8

McNeeley, S.M. 2012. Examining barriers and opportunities for sustainable adaptation to climate change in Interior Alaska. Climatic Change 111(3-4):835-857.

http://dx.doi.org/10.1007/s10584-011-0158-x

Meakin, S., and Kurvits, T. 2009. Assessing the impacts of climate change on food security in the Canadian Arctic. Arendal, Norway: GRID/Arendal.

http://www.grida.no/_res/site/file/publications/foodsec_updt LA_lo.pdf

Mohatt, G.V., Plaetke, R., Klejka, J., Luick, B., Lardon, C., Bersamin, A., Hopkins, S., et al. 2007. The Center for Alaska Native Health research study: A community-based participatory research study of obesity and chronic diseaserelated protective and risk factors. International Journal of Circumpolar Health 66(1):8-18.

http://dx.doi.org/10.3402/ijch.v66i1.18219

Mosteller, F., and Colditz, G.A. 1996. Understanding research synthesis (meta-analysis). Annual Review of Public Health 17(1):1-23.

http://dx.doi.org/10.1146/annurev.pu.17.050196.000245

National Research Council. 2003. Cumulative environmental effects of oil and gas activities on Alaska's North Slope. Washington, D.C.: National Academies Press.

O'Brien, K.L., and Leichenko, R.M. 2000. Double exposure: Assessing the impacts of climate change within the context of economic globalization. Global Environmental Change 10(3):221-232. http://dx.doi.org/10.1016/S0959-3780(00)00021-2

Pelling, M., and Dill, K. 2009. Disaster politics: Tipping points for change in the adaptation of sociopolitical regimes. Progress in Human Geography 34(1):21-37. http://dx.doi.org/10.1177/0309132509105004

Power, E., and Dietitians of Canada. 2005. Individual and household food insecurity in Canada: Position of dietitians of Canada. Canadian Journal of Dietetic Practice and Research 66(1):43-46.

http://dx.doi.org/10.3148/66.1.2005.43

Price, W.A. 1939. Nutrition and physical degeneration: On the problems of the Western diet and the obsession with nutrients. Vol. 8. New York: McGraw-Hill Book Company, Inc.

Receveur, O., Boulay, M., and Kuhnlein, H.V. 1997. Decreasing traditional food use affects diet quality for adult Dene/Metis in 16 communities of the Canadian Northwest Territories. Journal of Nutrition 127(11):2179-2186.

Rideout, K., Riches, G., Ostry, A., Buckingham, D., and MacRae, R. 2007. Bringing home the right to food in Canada: Challenges and possibilities for achieving food security. Public Health Nutrition 10(6):566-573.

http://dx.doi.org/10.1017/S1368980007246622 
Rosol, R., Huet, C., Wood, M., Lennie, C., Osborne, G., and Egeland, G.M. 2011. Prevalence of affirmative responses to questions of food insecurity: International Polar Year Inuit health survey, 2007-2008. International Journal of Circumpolar Health 70(5):488-497.

http://dx.doi.org/10.3402/ijch.v70i5.17862

Salem, E. 2005. The promise of MAPP: A transformational tool for public health practice. Journal of Public Health Management and Practice 11(5):379-380.

http://dx.doi.org/10.1097/00124784-200509000-00001

Schaefer, O., Timmermans, J.F.W., Eaton, R.D.P., and Matthews, A.R. 1980. General and nutritional health in two Eskimo populations at different stages of acculturation. Canadian Journal of Public Health 71(6):397-405.

Schuster, R.C., Gamberg, M., Dickson, C., and Chan, H.M. 2011. Assessing risk of mercury exposure and nutritional benefits of consumption of caribou (Rangifer tarandus) in the Vuntut Gwitchin First Nation community of Old Crow, Yukon, Canada. Environmental Research 111(6):881 - 887 .

http://dx.doi.org/10.1016/j.envres.2011.05.025

Skinner, K., Hanning, R.M., and Tsuji, L.J. 2014. Prevalence and severity of household food insecurity of First Nations people living in an on-reserve, sub-Arctic community within the Mushkegowuk Territory. Public Health Nutrition 17(1):31-39. http://dx.doi.org/10.1017/S1368980013001705

Snodgrass, J.J. 2013. Health of Indigenous circumpolar populations. Annual Review of Anthropology 42(1):69-87. http://dx.doi.org/10.1146/annurev-anthro-092412-155517

Statistics Canada. 2013. Household food insecurity, 2011-2012. http://www.statcan.gc.ca/pub/82-625-x/2013001/article/11889eng.htm
Stephenson, P.H. 1995. A persistent spirit: Towards understanding Aboriginal health in British Columbia. Victoria: Dept. of Geography, University of Victoria.

Thériault, S., Otis, G., Duhaime, G., and Furgal, C. 2005. The legal protection of subsistence: A prerequisite of food security for the Inuit of Alaska. Alaska Law Review 22(1):35-87.

Thornton, T.F. 1998. Alaska Native subsistence: A matter of cultural survival. Cultural Survival Quarterly 22(3):29-34.

Via Campesina. 1996. The right to produce and access to land. Voice of the Turtle.

http://www.voiceoftheturtle.org/library/1996\%20 Declaration\%20of\%20Food\%20Sovereignty.pdf

Weinfeld, N.S., Mills, G., Borger, M., Gearing, M., Macaluso, T., Montaquilla, J., and Zedlewski, S. 2014. Hunger in America 2014. Chicago, Illinois: Feeding America. http://help.feedingamerica.org/HungerInAmerica/hunger-inamerica-2014-full-report.pdf

Wesche, S.D., and Chan, H.M. 2010. Adapting to the impacts of climate change on food security among Inuit in the western Canadian Arctic. EcoHealth 7(3):361 - 373. http://dx.doi.org/10.1007/s10393-010-0344-8

Wheeler, P., and Thornton, T.F. 2005. Subsistence research in Alaska: A thirty year retrospective. Alaska Journal of Anthropology 3(1):69-103.

Wolfe, R.J., and Walker, R.J. 1987. Subsistence economies in Alaska: Productivity, geography, and development impacts. Arctic Anthropology 24(2):56-81. 